\title{
Enzyme immunoassays for IgG and IgM antibodies to Toxoplasma gondii based on enhanced chemiluminescence
}

\author{
C F Crouch
}

\begin{abstract}
Aims-To evaluate the clinical performance of enzyme immunoassays for IgG and IgM antibodies to Toxoplasma gondii based on enhanced chemiluminescence. Methods-Classification of routine clinical samples from the originating laboratories was compared with that obtained using the chemiluminescence based assays. Resolution of discordant results was achieved by testing in alternative enzyme immunoassays (IgM) or by an independent laboratory using the dye test (IgG).

Results-Compared with resolved data, the IgM assay was found to be highly specific $(100 \%)$ with a cut off selected to give optimal performance with respect to both the early detection of specific IgM and the detection of persistent levels of specific IgM (sensitivity $98 \%$ ). Compared with resolved data, the IgG assay was shown to have a sensitivity and a specificity of $99.4 \%$.

Conclusions-The Amerlite Toxo IgM assay possesses high levels of sensitivity and specificity. Assay interference due to rheumatoid factor like substances is not a problem. The Amerlite Toxo IgG assay possesses good sensitivity and specificity, but is less sensitive for the detection of seroconversion than methods detecting both IgG and IgM.

(f Clin Pathol 1995;48:652-657)
\end{abstract}

Keywords: Toxoplasma antibodies, immunoassay, enhanced chemiluminescence.

Toxoplasma gondii is an obligate protozoan parasite with a wide host range including mammals and birds. ${ }^{12}$ Humans can acquire toxoplasmosis via ingestion of mature oocytes (from contaminated soil or vegetable matter) or undercooked meats containing tissue cysts. ${ }^{34}$

Transplacental transmission of the parasite is possible and congenital infections occur in about $40 \%$ of pregnant women with acute phase toxoplasmosis. About $90 \%$ of neonates infected in utero are asymptomatic at birth but adverse sequelae, including chorioretinitis, convulsions and mental and psychomotor retardation may appear later in life. ${ }^{56}$

Serological tests can be used as a means of detecting specific antibody and hence the susceptibility of an individual to infection. Detection of $T$ gondii specific IgM can be used in conjunction with a rising IgG titre to distinguish between active and previous infection.

The development of two sensitive and specific enzyme immunoassays for the detection of $T$ gondii specific IgG and IgM based on enhanced chemiluminescence detection is reported.

\section{Methods}

ANTI-TOXOPLASMA IGM ASSAY PROCEDURES

Kodak Amerlite Toxo IgM assay

The Kodak Amerlite Toxo IgM assay uses an antibody class capture technique for the detection of $\operatorname{IgM}$ antibodies to $T$ gondii in human serum. Toxoplasma specific IgM antibodies are detected using a preformed complex comprising toxoplasma antigens, extracted from the $\mathrm{Rh}$ strain of $T$ gondii propagated in the peritoneal cavities of mice, complexed with horseradish peroxidase (HRP) labelled antitoxoplasma (p30) mouse monoclonal antibody (the conjugate complex).

Briefly, $10 \mu \mathrm{l}$ of patient sample (or control sera) was added to wells coated with mouse monoclonal antihuman IgM antibodies, and diluted with $200 \mu \mathrm{l}$ of assay reagent. The wells were incubated using an Amerlite shaker incubator for 30 minutes. During this incubation step, IgM class antibodies from the sample were captured specifically by these antihuman $\operatorname{IgM}$ antibodies. Unbound material was then removed by aspiration and washing; $100 \mu \mathrm{l}$ of conjugate complex was then dispensed into each well and incubated for 30 minutes using an Amerlite shaker incubator. During this incubation step, the complex was captured by any toxoplasma specific IgM that had been bound to the well during the first incubation step. At the end of the incubation, unbound material was removed by aspiration and washing. The addition of the signal reagent then produced a luminescent signal which was related to the concentration of the bound peroxidase. ${ }^{7}$ The light signals were read in an Amerlite analyser. Results were automatically calculated and expressed as a normalised signal relative to the cut off value. The cut off value for the assay was determined by multiplying the mean light signal of a control sample included in each assay run by $0 \cdot 89$. A result of less than 0.8 was interpreted as negative; a result of greater than 1.2 was interpreted as positive. A result between 0.8 and 1.2 was regarded as requiring a retest to confirm the result. A repeatedly retest result was interpreted as positive for IgM antibody to $T$ gondii. 
Sorin Biomedica ETI-ToxoK-M reverse and Organon Toxonstika IgM assays

These tests are both based on the antibody class capture procedure described above. Bound toxoplasma specific IgM from a diluted sample is detected by the addition of HRP labelled anti-toxoplasma antibody and toxoplasma antigen. A chromogenic substrate is then added and the intensity of the colour produced is related to the concentration of the bound peroxidase.

\section{BioMerieux Toxo immunosorbent agglutination assay}

This immunosorbent agglutination assay (ISAGA) is based on the antibody class capture procedure described above. In this assay bound toxoplasma specific IgM from a range of sample dilutions is visually detected by the agglutination of toxoplasma antigen. In the presence of specific IgM a visible mat forms at the bottom of the well.

\section{In-house ISAGA}

This was performed as described by Desmonts. ${ }^{8}$

ANTI-TOXOPLASMA IgG ASSAYS

Kodak Amerlite Toxo IgG assay

The Kodak Amerlite Toxo IgG assay is a two step antiglobulin assay for the detection of IgG antibodies to $T$ gondii in human serum. Briefly, $200 \mu \mathrm{l}$ of assay reagent was added to wells coated with antigen derived from physically disrupted purified toxoplasma tachyzoites (Rh strain) propagated in the peritoneal cavities of mice. Then, $10 \mu \mathrm{l}$ of patient sample (or control sera) was added and the wells incubated for one hour using an Amerlite shaker incubator. During this incubation period, toxoplasma specific antibody reacted with the antigen coated well. Unbound material was then removed by aspiration and washing. Conjugate $(100 \mu \mathrm{l})$, affinity purified rabbit antihuman IgG conjugated to HRP, was then dispensed into each well and incubated for 30 minutes using an Amerlite shaker incubator. During this incubation step, the conjugated antibody bound specifically to IgG antibody from the patient sample previously immobilised on the solid phase. At the end of the incubation, unbound material was removed by aspiration and washing. The HRP activity of the bound conjugate was measured by an enhanced luminescence reaction.

Results were automatically calculated by the Amerlite analyser and expressed as a normalised signal relative to the cut off value. The cut off value for the assay was determined by multiplying the mean light signal of a control sample included in each assay run by 0.85 . Although it is not appropriate to express test results, other than the dye test, in international units, in order to provide a point of comparison with other commercial assays, the Amerlite cut off value is equivalent to approximately $13 \mathrm{IU} /$ $\mathrm{ml}$ (World Health Organisation International
Standard for Anti-Toxoplasma Serum TOXS 60 ). A result of less than 0.8 was interpreted as negative; a result of greater than 1.2 was interpreted as positive. A result between 0.8 and 1.2 was regarded as requiring a retest to confirm the result. A repeatedly retest result was interpreted as positive for IgG antibody to $T$ gondii.

\section{Sorin Biomedica ETI-ToxoK-G}

This is a conventional two step antiglobulin assay as described above. In this assay bound toxoplasma specific IgG is detected using an HRP labelled antihuman IgG antibody. A chromogenic substrate is then added and the intensity of the colour produced is proportional to the concentration of the bound peroxidase. This assay is quantitative, and has a working range of 0 to $150 \mathrm{IU} / \mathrm{ml}$ (World Health Organisation International Standard for AntiToxoplasma Serum TOXS 60) with a cut off set at $15 \mathrm{IU} / \mathrm{ml}$.

High sensitivity agglutination assay

This high sensitivity agglutination assay (HSA) was performed using formalin fixed tachyzoites as described by Desmonts and Remington. ${ }^{9}$

Dye Test

The Sabin-Feldman dye test was performed using twofold dilutions of each test serum. ${ }^{10}$

\section{CLINICAL SAMPLES}

Results obtained, by independent clinical laboratories in France and Italy, using the Abbott IMx Toxo-G assay, on 1248 samples from routine screening populations were compared with the results obtained using the Amerlite Toxo IgG assay at Kodak Clinical Diagnostics Ltd (Chalfont St Giles, Bucks, UK). Discordant results were resolved using the Sabin-Feldman dye test performed by a specialist reference laboratory.

Results obtained, by independent clinical laboratories in France and Italy, using the Abbott IMx Toxo-M assay, on 436 samples from routine screening populations were compared with the results obtained using the Amerlite Toxo IgG assay at Kodak Clinical Diagnostics Ltd. Discordant results were resolved by testing in a panel of alternative assays comprising ISAGA (BioMerieux), and the Sorin Biomedica ETI-ToxoK-M reverse and, where appropriate, testing by a specialist reference laboratory.

One hundred and two samples positive for rheumatoid factor were tested using the Toxo IgM assay; of these, 100 were also tested in the Toxo IgG assay. The antibody status of any sample found to be positive or to need retesting in the Toxo IgM assay was confirmed by testing in a panel of alternative assays (Sorin Biomedica ETI-ToxoK-M reverse, BioMerieux Toxo-ISAGA and Organon Toxonostika IgM) or by testing at an independent specialist reference centre, as appropriate. The antibody 
Table 1 Comparison of the Kodak Amerlite Toxo IgM assay with Abbott IMx Toxo IgM assay

\begin{tabular}{|c|c|c|c|c|c|c|c|}
\hline \multirow[b]{2}{*}{ Abbott IMx } & \multirow[b]{2}{*}{ Number of serum samples } & \multicolumn{3}{|l|}{ Amerlite } & \multicolumn{3}{|c|}{$\%$ Agreement $^{* *}$} \\
\hline & & Negative & Retest & Positive & Negative & Positive & Overall \\
\hline Negative & $\begin{array}{c}317 \\
(335)\end{array}$ & $315(335)$ & $\begin{array}{l}1 \dagger \\
(0)\end{array}$ & $\begin{array}{l}1+ \\
(0)\end{array}$ & $99 \cdot 4$ & & 03.1 \\
\hline $\begin{array}{l}\text { Retest } \\
\text { (unresolved) } \\
\text { Positive }\end{array}$ & $\begin{array}{c}10 \\
(12) \\
109 \\
(89)\end{array}$ & $\begin{array}{l}6^{*} \\
(6) \\
22^{*} \\
(2)\end{array}$ & $\begin{array}{c}3 \ddagger \\
(5) \\
7 \oint \\
(6)\end{array}$ & $\begin{array}{c}1 \neq \\
(1) \\
80 \\
(81)\end{array}$ & & $79 \cdot 8$ & \\
\hline
\end{tabular}

* Twenty of 28 were resolved (see methods) as negative. Six were unresolved (five ISAGA positive, Sorin ToxoK M negative; one ISAGA negative, Sorin ToxoK M positive), and two were resolved as true positives (ISAGA and Sorin ToxoK M positive).

† Two of two were unresolved (see methods) (ISAGA positive, Sorin ToxoK M negative).

$¥$ Four of four were resolved (see methods) as positive.

\$Four of seven were unresolved (see methods) (ISAGA positive, Sorin ToxoK M negative).

** Amerlite retest results were treated as consistent with Amerlite positive results for the calculation of percentage agreement.

Note: Figures in brackets denote resolved data, with the exception of the retest data where resolution was incomplete.

status of any sample found to be positive or to need retesting in the Toxo IgG assay was confirmed by testing using the Sorin Biomedica ETI-ToxoK-G reverse or by testing at an independent special reference centre, as appropriate.

Serum samples obtained from patients with serological evidence (in-house ISAGA, HSA and dye test) of recent infection were tested using the Amerlite Toxo IgG and Toxo IgM assays. The Toxo IgM assay was also used to determine the presence of specific IgM in samples from patients with serological evidence (HSA and dye test) of past infection and also in samples taken at delivery from women infected during the first trimester of pregnancy.

\section{ASSAY PRECISION}

For either assay, within assay precision was calculated as the root mean squared (RMS) of the percentage coefficient of variation (CV\%) determined in each of six assays using $10 \mathrm{rep}$ licates of each of three control serum samples whose values were spread throughout the assay range. Between assay precision was calculated using the mean value of duplicate results, for the same control serum samples, from each of 20 assays using three different kit batches.

\section{Results}

SENSITIVITY AND SPECIFICITY

A comparison of the Amerlite Toxo IgM assay results and the sample classification obtained by the originating laboratory (using the Abbott IMx Toxo IgM assay) for the 436 routine clinical samples tested for toxoplasma specific IgM antibody is shown in table 1 . Of the 317 samples negative by the Abbott IMx assay, 315 were also classified as negative in the Amerlite assay (99.4\% agreement). Of 109 samples found to be positive by Abbott IMx, 87 were found to be positive or to need retesting by the Amerlite assay (79.8\% agreement). Overall agreement was $93 \cdot 1 \%(406 / 436)$. Compared with the resolved data (table 1), and treating Amerlite retest results as consistent with positive results, the sensitivity of the Amerlite Toxo IgM assay was calculated to be $97 \cdot 8 \%(87 / 89)$, specificity to be $100 \%$ (335/335) and accuracy to be $98 \cdot 2 \%(428 / 436)$.

A comparison of the Amerlite Toxo IgG assay results and the sample classification obtained by the originating laboratory (using the Abbott IMx Toxo IgG assay) for the 1248 routine clinical samples tested for toxoplasma specific IgG antibody is shown in table 2 . Of the 633 samples negative by the Abbott IMx assay, 598 were also classified as negative in the Amerlite assay (94.5\% agreement). Of 615 samples found to be positive by Abbott IMx, 597 were found to be positive or to need retesting by the Amerlite assay ( $97 \cdot 1 \%$ agreement). Overall agreement was $95 \cdot 8 \%$ (1195/ 1248). Compared with the resolved data (table 2 ), and treating Amerlite retest results as consistent with positive results, sensitivity of the Amerlite Toxo IgG assay was calculated to be $99 \cdot 4 \%(628 / 632)$, specificity to be $99 \cdot 4 \%(612 /$ $616)$ and accuracy to be $99 \cdot 4 \%(1240 / 1248)$.

\section{DETECTION OF RECENT INFECTION}

Seroconversion

Nine series of patient samples showing IgG seroconversion as indicated by HSA were tested using both the Amerlite Toxo IgG and the Toxo IgM assays (table 3 ). With the exception of series 3, all series tested in the Amerlite Toxo IgM assay (series 1 to 6 inclusive) showed agreement with both the dye test and ISAGA results. Series 1 did not show seroconversion by the Amerlite Toxo IgG assay; this was in

Table 2 Comparison of the Kodak Amerlite Toxo IgG assay with Abbott IMx Toxo IgG assay

\begin{tabular}{|c|c|c|c|c|c|c|c|}
\hline \multirow[b]{2}{*}{ Abbott IMx } & \multirow[b]{2}{*}{ Number of serum samples } & \multicolumn{3}{|l|}{ Amerlite } & \multicolumn{3}{|c|}{$\%$ Agreement\$ } \\
\hline & & Negative & Retest & Positive & Negative & Positive & Overall \\
\hline $\begin{array}{l}\text { Negative } \\
\text { Positive }\end{array}$ & $\begin{array}{c}633 \\
(616) \\
615 \\
(632)\end{array}$ & $\begin{array}{c}598 \\
(612) \\
18^{*} \\
(4)\end{array}$ & $\begin{array}{c}1 \dagger \\
(0) \\
3 \\
(4)\end{array}$ & $\begin{array}{c}34 \ddagger \\
(4) \\
594 \\
(624)\end{array}$ & $94 \cdot 5$ & $97 \cdot 1$ & $95 \cdot 8$ \\
\hline
\end{tabular}

* Fourteen of 18 resolved (by an independent reference laboratory) as negative, the remaining four were resolved as positive. † Sample resolved as positive by an independent reference laboratory.

\$Thirty of 34 resolved (by an independent reference laboratory) as positive, the remaining four were resolved as negative.

\$ Thirty of 34 resolved (by an independent reference laboratory) as positive, the remaining four were resolved as negative.

Amerlite retest results were treated as consiste
Note: Figures in brackets denote resolved data. 
Table 3 Results from patient samples showing seroconversion to Toxoplasma

\begin{tabular}{|c|c|c|c|c|c|c|c|c|c|}
\hline \multirow[b]{2}{*}{ Sample ID } & \multirow[b]{2}{*}{ Sample type } & \multirow[b]{2}{*}{ Date } & \multicolumn{2}{|c|}{ Amerlite Toxo IgM } & \multicolumn{2}{|c|}{ Amerlite Toxo IgG } & \multirow[b]{2}{*}{$I S A G A$} & \multirow[b]{2}{*}{ Dye test } & \multirow[b]{2}{*}{$H S A$} \\
\hline & & & Result & Flag & Result & Flag & & & \\
\hline $\begin{array}{r}8713 \\
8714 \\
10123\end{array}$ & Seroconversion series 1 & $\begin{array}{l}15.02 .92 \\
14.03 .92 \\
28.03 .92\end{array}$ & $\begin{array}{l}0.05 \\
1.48 \\
1.19\end{array}$ & $\begin{array}{l}\text { Negative } \\
\text { Positive } \\
\text { Positive }\end{array}$ & $\begin{array}{l}0 \cdot 07 \\
0 \cdot 09 \\
0 \cdot 1\end{array}$ & $\begin{array}{l}\text { Negative } \\
\text { Negative } \\
\text { Negative }\end{array}$ & $\begin{array}{l}\text { Negative } \\
\text { Positive } \\
\text { Positive }\end{array}$ & $\begin{array}{l}\text { Negative } \\
\text { Positive } \\
\text { Positive }\end{array}$ & $\begin{array}{l}\text { Negative } \\
\text { Negative } \\
\text { Negative }\end{array}$ \\
\hline $\begin{array}{l}12457 \\
12458 \\
14208\end{array}$ & Seroconversion series 2 & $\begin{array}{l}22.02 .92 \\
15.04 .92 \\
02.05 .92\end{array}$ & $\begin{array}{l}0 \cdot 05 \\
6 \cdot 74 \\
6 \cdot 87\end{array}$ & $\begin{array}{l}\text { Negative } \\
\text { Positive } \\
\text { Positive }\end{array}$ & $\begin{array}{l}0.07 \\
1 \cdot 26 \\
3.02\end{array}$ & $\begin{array}{l}\text { Negative } \\
\text { Positive } \\
\text { Positive }\end{array}$ & $\begin{array}{l}\text { Negative } \\
\text { Positive } \\
\text { Positive }\end{array}$ & $\begin{array}{l}\text { Negative } \\
\text { Positive } \\
\text { Positive }\end{array}$ & $\begin{array}{l}\text { Negative } \\
16 \\
200\end{array}$ \\
\hline $\begin{array}{l}1992 \\
1993 \\
1994\end{array}$ & Seroconversion series 3 & $\begin{array}{l}06.91 \\
12.91 \\
01.92\end{array}$ & $\begin{array}{l}0.04 \\
0.51 \\
0.45\end{array}$ & $\begin{array}{l}\text { Negative } \\
\text { Negative } \\
\text { Negative }\end{array}$ & E & E & $\begin{array}{l}\text { Negative } \\
\text { Positive } \\
\text { Positive }\end{array}$ & $\begin{array}{l}\text { Negative } \\
\text { Positive } \\
\text { Positive }\end{array}$ & $\begin{array}{l}\text { Negative } \\
2 \\
100\end{array}$ \\
\hline $\begin{array}{l}6030 \\
6029 \\
5457\end{array}$ & Seroconversion series 4 & $\begin{array}{l}09.01 .92 \\
31.01 .92 \\
18.02 .92\end{array}$ & $\begin{array}{l}0 \cdot 05 \\
7 \cdot 67 \\
7 \cdot 34\end{array}$ & $\begin{array}{l}\text { Negative } \\
\text { Positive } \\
\text { Positive }\end{array}$ & $\begin{array}{l}0 \cdot 08 \\
0 \cdot 18 \\
1 \cdot 24\end{array}$ & $\begin{array}{l}\text { Negative } \\
\text { Negative } \\
\text { Positive }\end{array}$ & $\begin{array}{l}\text { Negative } \\
\text { Positive } \\
\text { Positive }\end{array}$ & $\begin{array}{l}\text { Negative } \\
\text { Positive } \\
\text { Positive }\end{array}$ & $\begin{array}{c}\text { Negative } \\
2 \\
100\end{array}$ \\
\hline $\begin{array}{l}17003 \\
17005 \\
18913\end{array}$ & Seroconversion series 5 & $\begin{array}{l}04.05 .92 \\
04.06 .92 \\
22.06 .92\end{array}$ & $\begin{array}{l}0 \cdot 09 \\
3 \cdot 72 \\
4 \cdot 46\end{array}$ & $\begin{array}{l}\text { Negative } \\
\text { Positive } \\
\text { Positive }\end{array}$ & $\begin{array}{l}0 \cdot 06 \\
0 \cdot 10 \\
0 \cdot 42\end{array}$ & $\begin{array}{l}\text { Negative } \\
\text { Negative } \\
\text { Negative }\end{array}$ & $\begin{array}{l}\text { Negative } \\
\text { Positive } \\
\text { Positive }\end{array}$ & $\begin{array}{l}\text { Negative } \\
\text { Positive } \\
\text { Positive }\end{array}$ & $\begin{array}{l}\text { Negative } \\
\text { Negative } \\
16\end{array}$ \\
\hline $\begin{array}{l}16475 \\
16476 \\
16477\end{array}$ & Seroconversion series 6 & $\begin{array}{l}18.03 .92 \\
14.04 .92 \\
23.05 .92\end{array}$ & $\begin{array}{l}0.04 \\
0.92 \\
0.89\end{array}$ & $\begin{array}{l}\text { Negative } \\
\text { Retest } \\
\text { Retest }\end{array}$ & $\begin{array}{l}0 \cdot 06 \\
0 \cdot 18 \\
1 \cdot 68\end{array}$ & $\begin{array}{l}\text { Negative } \\
\text { Negative } \\
\text { Positive }\end{array}$ & $\begin{array}{l}\text { Negative } \\
\text { Positive } \\
\text { Positive }\end{array}$ & $\begin{array}{l}\text { Negative } \\
\text { Positive } \\
\text { Positive }\end{array}$ & $\begin{array}{l}\text { Negative } \\
2 \\
100\end{array}$ \\
\hline $\begin{array}{l}2534 \\
2535 \\
2536\end{array}$ & Seroconversion series 7 & $\begin{array}{l}03.11 .92 \\
15.12 .92 \\
30.12 .92\end{array}$ & $\bar{z}$ & - & $\begin{array}{l}0.25 \\
0.53 \\
1.54\end{array}$ & $\begin{array}{l}\text { Negative } \\
\text { Negative } \\
\text { Positive }\end{array}$ & $\begin{array}{l}\text { Negative } \\
\text { Positive } \\
\text { Positive }\end{array}$ & & $\begin{array}{l}\text { Negative } \\
16 \\
64\end{array}$ \\
\hline $\begin{array}{l}3340 \\
3341 \\
2396 \\
3342\end{array}$ & Seroconversion series 8 & $\begin{array}{l}30.11 .92 \\
18.12 .92 \\
15.01 .93 \\
01.02 .93\end{array}$ & $\begin{array}{l}- \\
-\end{array}$ & $\frac{-}{-}$ & $\begin{array}{l}0.09 \\
0.07 \\
0.97 \\
2 \cdot 15\end{array}$ & $\begin{array}{l}\text { Negative } \\
\text { Negative } \\
\text { Retest } \\
\text { Positive }\end{array}$ & $\begin{array}{l}\text { Negative } \\
\text { Positive } \\
\text { Positive } \\
\text { Positive }\end{array}$ & & $\begin{array}{l}\text { Negative } \\
\text { Negative } \\
32 \\
200\end{array}$ \\
\hline $\begin{array}{r}36138 \\
36139 \\
3085\end{array}$ & Seroconversion series 9 & $\begin{array}{l}23.11 .92 \\
23.12 .92 \\
29.01 .93\end{array}$ & E & - & $\begin{array}{l}0.08 \\
0.31 \\
2.00\end{array}$ & $\begin{array}{l}\text { Negative } \\
\text { Negative } \\
\text { Positive }\end{array}$ & $\begin{array}{l}\text { Negative } \\
\text { Positive } \\
\text { Positive }\end{array}$ & & $\begin{array}{l}\text { Negative } \\
16 \\
400\end{array}$ \\
\hline
\end{tabular}

Table 4 Results from patient samples showing rising IgG titres to Toxoplasma

\begin{tabular}{|c|c|c|c|c|c|c|c|c|c|}
\hline \multirow[b]{2}{*}{ Sample ID } & \multirow[b]{2}{*}{ Sample type } & \multirow[b]{2}{*}{ Date } & \multicolumn{2}{|c|}{ Amerlite Toxo IgM } & \multicolumn{2}{|c|}{ Amerlite Toxo IgG } & \multirow[b]{2}{*}{$I S A G A$} & \multirow[b]{2}{*}{ Dye test } & \multirow[b]{2}{*}{$H S A$} \\
\hline & & & Result & Flag & Result & Flag & & & \\
\hline $\begin{array}{l}10710 \\
12852\end{array}$ & Rising IgG pair 1 & $\begin{array}{l}03.04 .92 \\
22.04 .92\end{array}$ & $\begin{array}{l}4 \cdot 30 \\
3 \cdot 86\end{array}$ & $\begin{array}{l}\text { Positive } \\
\text { Positive }\end{array}$ & $\begin{array}{l}1.44 \\
2 \cdot 71\end{array}$ & $\begin{array}{l}\text { Positive } \\
\text { Positive }\end{array}$ & $\begin{array}{l}\text { Positive } \\
\text { Positive }\end{array}$ & $\begin{array}{l}\text { Positive } \\
\text { Positive }\end{array}$ & $\begin{array}{r}64 \\
400\end{array}$ \\
\hline $\begin{array}{l}6971 \\
9164\end{array}$ & Rising IgG pair 2 & $\begin{array}{l}26.02 .92 \\
18.03 .92\end{array}$ & $\begin{array}{l}3 \cdot 31 \\
2 \cdot 63\end{array}$ & $\begin{array}{l}\text { Positive } \\
\text { Positive }\end{array}$ & $\begin{array}{l}0 \cdot 19 \\
1 \cdot 28\end{array}$ & $\begin{array}{l}\text { Negative } \\
\text { Positive }\end{array}$ & $\begin{array}{l}\text { Positive } \\
\text { Positive }\end{array}$ & $\begin{array}{l}\text { Positive } \\
\text { Positive }\end{array}$ & $\begin{array}{r}4 \\
16\end{array}$ \\
\hline $\begin{array}{l}2596 \\
4824\end{array}$ & Rising IgG pair 3 & $\begin{array}{l}21.01 .92 \\
11.02 .92\end{array}$ & $\begin{array}{l}3.06 \\
2.56\end{array}$ & $\begin{array}{l}\text { Positive } \\
\text { Positive }\end{array}$ & $\begin{array}{l}1.67 \\
3.63\end{array}$ & $\begin{array}{l}\text { Positive } \\
\text { Positive }\end{array}$ & $\begin{array}{l}\text { Positive } \\
\text { Positive }\end{array}$ & $\begin{array}{l}\text { Positive } \\
\text { Positive }\end{array}$ & $\begin{array}{l}100 \\
400\end{array}$ \\
\hline $\begin{array}{r}7631 \\
12192\end{array}$ & Rising IgG pair 4 & $\begin{array}{l}09.03 .92 \\
16.04 .92\end{array}$ & $\begin{array}{l}5 \cdot 25 \\
4 \cdot 45\end{array}$ & $\begin{array}{l}\text { Positive } \\
\text { Positive }\end{array}$ & - & - & $\begin{array}{l}\text { Positive } \\
\text { Positive }\end{array}$ & $\begin{array}{l}\text { Positive } \\
\text { Positive }\end{array}$ & $\begin{array}{l}16 \\
40\end{array}$ \\
\hline $\begin{array}{l}11177 \\
11900\end{array}$ & Rising IgG pair 5 & $\begin{array}{l}05.03 .92 \\
15.04 .92\end{array}$ & $\begin{array}{l}3 \cdot 13 \\
1 \cdot 45\end{array}$ & $\begin{array}{l}\text { Positive } \\
\text { Positive }\end{array}$ & - & - & $\begin{array}{l}\text { Positive } \\
\text { Positive }\end{array}$ & $\begin{array}{l}\text { Positive } \\
\text { Positive }\end{array}$ & $\begin{array}{r}8 \\
800\end{array}$ \\
\hline $\begin{array}{l}26174 \\
26175\end{array}$ & Rising IgG pair 6 & $\begin{array}{l}09.07 .92 \\
28.08 .92\end{array}$ & $\begin{array}{l}1 \cdot 63 \\
2 \cdot 41\end{array}$ & $\begin{array}{l}\text { Positive } \\
\text { Positive }\end{array}$ & - & - & $\begin{array}{l}\text { Positive } \\
\text { Positive }\end{array}$ & $\begin{array}{l}\text { Positive } \\
\text { Positive }\end{array}$ & $\begin{array}{r}1 \\
100\end{array}$ \\
\hline
\end{tabular}

agreement with the results obtained in the HSA. Series 5 also failed to show seroconversion by the Amerlite Toxo IgG Assay, although sample number 18913 (Amerlite value 0.42 ) is elevated compared with the two previous samples (Amerlite values $\leq 0 \cdot 1$ ). Of the remaining series tested by the Amerlite Toxo IgG assay, numbers $4,6,7,8$, and 9 showed seroconversion one sample later than the corresponding HSA results for that series. Seroconversion for series 2 was found to be in agreement between Amerlite and HSA results.

\section{Rising toxoplasma IgG titre}

Six pairs of samples showing a significant rise in toxoplasma IgG titre by HSA were tested in both the Amerlite Toxo IgG and the Toxo IgM assays (table 4). All samples were positive for toxoplasma IgM by the Amerlite assay, suggestive of a recent infection. These results are in agreement with those obtained by the dye test and ISAGA. In addition, none of 10 paired samples from patients with a past toxoplasma infection (as defined by a non-rising toxoplasma IgG titre by HSA) were positive by the Amerlite Toxo IgM assay (data not shown). The three pairs tested by the Amerlite Toxo IgG assay (pairs 1,2 and 3) all showed an increase in result and were thus in agreement with the HSA result.

\section{PERSISTENCE OF ANTI-TOXOPLASMA IgM AFTER} INFECTION

Ten samples, taken at delivery from women infected during the first trimester of pregnancy, thus at least six months after infection, were tested (table 5). All samples were positive by dye test and HSA, nine of 10 were positive by ISAGA and two of 10 were positive in the Amerlite IgM test.

\section{REACTIVITY WITH RHEUMATOID FACTOR}

Of the panel of 102 rheumatoid factor samples tested by the Amerlite Toto IgM assay, all were 
Table 5 Persistence of anti-toxoplasma IgM after infection (samples taken more than six months after infection)

\begin{tabular}{rlllll}
\hline & \multicolumn{2}{l}{ Amerlite Toxo IgM } & & & \\
\cline { 2 - 3 } Sample ID & Result & Flag & ISAGA & Dye test & HSA \\
\hline 19100 & 0.53 & Negative & Positive & Positive & 400 \\
19147 & 1.10 & Retest & Positive & Positive & 50 \\
19384 & 0.37 & Negative & Positive & Positive & 200 \\
43474 & 1.58 & Positive & Positive & Positive & 100 \\
4216 & 1.09 & Retest & Positive & Positive & 16 \\
10747 & 1.48 & Positive & Positive & Positive & 400 \\
7750 & 0.92 & Retest & Positive & Positive & 200 \\
15264 & 0.47 & Negative & Borderline Positive & 400 \\
8845 & 1.11 & Retest & Positive & Positive & 100 \\
21109 & 1.05 & Retest & Positive & Positive & 200 \\
\hline & & & & &
\end{tabular}

found to be negative for anti-toxoplasma IgM. Of the panel of 100 rheumatoid factor samples tested by the Amerlite Toxo IgG assay, 29 were found to be positive for anti-toxoplasma IgG and their antibody status confirmed by additional testing.

\section{SAMPLE EFFECTS}

The clinical interpretation of the Amerlite assays was not affected by the physical properties of any of the samples studied-for example, repeated freeze thawing, heat treatment $\left(56^{\circ} \mathrm{C}\right.$ for 30 minutes), lipaemia, etc (data not shown).

\section{ASSAY PRECISION}

In the Amerlite Toxo IgM assay the mean value for control $\mathrm{C} 1$ was 0.99 (range $0 \cdot 85-1 \cdot 18$ ) with a CV\% for between assay precision of $9 \cdot 1$ and a RMS CV\% for within assay precision of $7 \cdot 2$. The mean value for control $\mathrm{C} 2$ was $2 \cdot 34$ (range $2 \cdot 11-3 \cdot 09$ ) with a CV\% for between assay precision of 10.3 and a RMS CV\% for within assay precision of 3.6 . The mean value for control C3 was 6.92 (range 5.91-7.95) with a $\mathrm{CV} \%$ for between assay precision of 9.8 and a RMS CV\% for within assay precision of $2 \cdot 7$.

In the Amerlite Toxo IgG assay the mean value for control C4 was 1.81 (range 1.61 $2 \cdot 16$ ) with a CV\% for between assay precision of $9 \cdot 4$ and a RMS CV\% for within assay precision of 8.8. The mean value for control $\mathrm{C} 5$ was $4 \cdot 14$ (range $3 \cdot 47-4.56$ ) with a CV\% for between assay precision of 8.1 and a RMS $\mathrm{CV} \%$ for within assay precision of $4 \cdot 8$. The mean value for control C6 was 6.07 (range 5.43-6.91) with a CV\% for between assay precision of $7 \cdot 7$ and a RMS CV\% for within assay precision of $4 \cdot 5$.

\section{Discussion}

In most individuals, infection with $T$ gondii is either asymptomatic or is accompanied by a range of generalised symptoms making a differential diagnosis difficult. Accurate serological data are essential, particularly for women infected during pregnancy where the patient may be offered additional testing including invasive procedures such as amniocentesis to confirm whether the infection has been transmitted to the fetus. ${ }^{1112}$

For each Amerlite assay, the performance criteria outlined in this paper are derived by comparison with a single alternative com- mercially available enzyme immunoassay followed by resolution of any discrepant samples. This regimen does not, however, address the possibility of both test and comparator assays generating the same, incorrect, results. The comparator assays selected for the evaluation not only use different detection systems (enhanced chemiluminescence versus fluorescence), but also use different enzymes in the conjugates, different species of antibodies and methods of antigen preparation as well as in the case of the IgM assays completely different assay formats (IgM capture versus indirect assay). This minimises the likelihood of the comparator and test assays sharing false reactivities. For the reasons outlined above, absolute confirmation of infection by clinical diagnosis is rare and so could not be used for the selection of samples.

The precision data for both the Amerlite Toxo IgG and Toxo IgM assays indicates that consistent results can be obtained across the respective assay ranges. Furthermore, the reproducibility of the assay in the retest region is such that a change in classification (from negative to positive or vice versa) will not occur.

Unlike specific IgG antibodies which typically persist for life, specific IgM antibodies begin to decline after several months, but may in some instances persist for over a year. ${ }^{13-15}$ To ensure that a primary infection is detected as early as possible, it is important to ensure that any toxoplasma IgM assay is as sensitive as possible. However, a sensitive test may detect specific $\operatorname{IgM}$ relatively late after infection and therefore act as a poor indicator of recent infection. As there is no definitive reference method for the detection of toxoplasma IgM, the best measure of assay performance in terms of early detection is obtained through the measurement of samples from defined cases of recent infection or from seroconversion samples. Overall, the Amerlite Toxo IgM assay showed a high level of sensitivity, equivalent to that seen with a variety of different technologies recognised as possessing high sensitivity for the detection of recent infection. In the Amerlite Toxo IgM assay, only two of 10 samples taken from patients infected in early pregnancy remained positive six months after infection. Thus, from the limited study performed the clinical sensitivity of this assay appears to give a more useful window of IgM detection for routine screening than-for example, ISAGA, where antibody reactivity may persist for 18 months. ${ }^{16}$ Confirmation of this observation will, however, require a larger study to be performed. False positive results due to rheumatoid factor-like substances have been ascribed to IgM assays irrespective of whether they use indirect (antigen coated solid phase) or direct (IgM capture) procedures, although the phenomenon is more significant with indirect assays. ${ }^{17}$ The results reported here indicate that this type of assay interference is not a problem with the Amerlite Toxo IgM assay and this may explain the high specificity observed in the routine screening population tested.

The dye test is regarded as the definitive test for the detection of toxoplasma specific 
antibody. It is, however, not specific for IgG antibodies alone and has been shown to react with IgM. ${ }^{18}$ Additionally, the dye test measures antibodies reacting with whole viable tachyzoites, thus predominantly antibodies reactive with surface proteins. The Amerlite Toxo IgG assay is specific for IgG and uses an antigen preparation comprised of disrupted tachyzoites to coat the solid phase, hence the antibody profiles measured by the two procedures cannot be identical. To obtain a measure of clinical performance, it was therefore decided to minimise these effects by comparing results obtained with the Amerlite assay with those obtained using another commercially available enzyme immunoassay, and resolving any discrepancies using the dye test. No clear pattern of discrepant results was observed, although most samples apparently false positive by Amerlite were found to have only low levels of specific antibody, suggesting a toxoplasma infection sometime previously. This ability to detect "old" infection is crucial for determining the susceptibility of an individual to infection. A patient with a false negative result will not be retested during pregnancy leading to the possibility of an infection remaining undetected. Conversely, a patient with an initial false positive result will continue to be monitored throughout pregnancy and this may lead to a false indication of seroconversion and the associated anxieties for the patient. It is likely that the differences observed between the assays in this study are due to the type of antigen preparation used.

The Amerlite assay protocols used in this study do not generate fully quantitative results as defined by calibration against a standard curve. The Amerlite values produced by the assays are, however, directly related to the antibody concentration in the sample and can therefore be used as an aid in the interpretation of data from cases of recent infection.

This study clearly indicates that the Amerlite Toxo IgG assay (like many enzyme immunoassays) is less sensitive for the detection of seroconversion than the HSA, with a delay of approximately 10 to 15 days in pick up leading to two of the eight series remaining negative (numbers 1 and 5), although series 1 also remained negative by HSA. This lack of sensitivity can be explained by the IgG specificity of the Amerlite Toxo IgG assay as discussed earlier. Assays that measure both IgG and IgM (for example, the dye test) should detect seroconversion earlier than an IgG specific assay as following infection, $\operatorname{IgM}$ appears before IgG. With the exception of series 3, the detection of seroconversion using the Amerlite Toxo IgM assay was in agreement with the HSA results. As mentioned earlier, the cut off value for this assay has been selected to give an optimal window of IgM detection for routine screening by minimising the detection of persistent low levels of IgM antibody. There is a six month gap between the first two time points in seroconversion series 3 . It is considered likely that the raised Amerlite value $(0.51$ compared with a typical negative value of $<0 \cdot 1$ ), although flagged negative, reflects the tail end of the IgM response, thus suggesting that an infection may have occurred soon after the first bleed was obtained. Unfortunately, this sample was not available for testing in the Amerlite Toxo IgG assay, but data from the other tests performed support this hypothesis. Generally, in order to determine the onset of infection more accurately, it may be more useful to use a combined screening programme (similar to that set up in France in 1978) utilising both IgG and IgM testing. The data presented in this report indicate that such an approach would be as sensitive as the dye test at detecting seroconversion, without the requirements for the facilities to handle live tachyzoites.

I thank Dr P Thulliez for his assistance in the clinical evaluation of the Amerlite toxoplasma assays. I gratefully acknowledge the expert technical assistance of J Tyrell, B Pierce, J Heafford, K Pollard, and W Spencer-Smith and thank M Jones and J Diment for thoughtful review and suggestions.

1 Frenkel JK. Toxoplasmosis. In: Binford $\mathrm{CH}$, Conner DH, eds. Pathology of tropical and extraordinary diseases. Washington DC: RL Press, 1976:284-300.

2 Remington JS, Desmonts G. Toxoplasmosis. In: Remington JS, Klein JO, eds. Infectious diseases of the fetus and newborm infant. 3rd edn. Philadelphia: WB Saunders, 1990:89-195.

3 Beattie CP. The ecology of congenital toxoplasmosis. Eco Dis 1982;1:3-20.

4 Frenkel JK. Toxoplasma in and around us. Bioscience 1973; 23:343-52.

5 Desmonts G, Couvreur J. Toxoplasmosis in pregnancy and its transmission to the fetus. Bull NY Acad Med 1974;50:

6 Wilson CB, Remington JS, Stagno S, Reynolds DW. Development of adverse sequelae in children born with subvelopment of adverse sequelae in children born with sub-
clinical congenital toxoplasma infection. Pediatrics 1980; 66:767-74.

7 Whitehead TP, Thorpe GHG, Carter TJN, Groucutt C, Kricka LJ. Enhanced luminescence procedure for sensitive determination of peroxidase-labelled conjugates in immunoassay. Nature 1983;305:158-9.

8 Desmonts G. IgM immunosorbent agglutination assay (I.S.Ag.A.). Lyon Med 1982;248:37-41.

9 Desmonts G, Remington JS. Direct agglutination test for diagnosis of toxoplasma infection: method for increasing

10 Sabin AB, Feld specificity. $f$ Clin Microbiol $1980,11.562-8$ of a new immunity phenomenon affecting a protozoan parasite (Toxoplasma). Science 1948;108:660-3.

11 Daffos F, Forestier F, Capella-Pavlovsky M. Prenatal management of 746 pregnancies at risk for congenital toxoagement of 746 pregnancies at risk for con
plasmosis. $N$ Engl $\mathcal{F}$ Med 1988;318:271-5.

12 Desmonts G, Couvreur J. Congenital toxoplasmosis: a prospective study of the offspring of 542 women who acquired toxoplasmosis during pregnancy. In: Thalhammer $O$ Baumgarten K, Pollak A, eds. Perinatal Medicine Sixth European Congress. Stuttgart: Georg Thieme, 1979:3271.

13 Brooks RG, McCabe RE, Remington JS. Role of serology in the diagnosis of toxoplasmic lymphadenopathy. Rev Infect Dis 1987;9:1055-62.

14 Derouin F, Rabian-Herzog C, Sulahian A. Longitudinal study of the specific humoral and cellular response to Toxoplasma gondii in a patient with acquired toxoToxoplasma gondii in a patient with acquired
plasmosis. f Clin Lab Immunol 1989;30:97-102.

15 Sulzer AJ, Franco EL, Takafuji E, Benenson M, Walls KW, Greenup RL. An oocyst transmitted outbreak of toxoplasmosis: Patterns of immunoglobulin $\mathrm{G}$ and $\mathrm{M}$ over one year. Am f Trop Med Hyg 1986;35:290-6.

16 Duffy KT, Wharton PJ, Johnson JD, New L, Holliman RE. Assessment of an immunoglobulin-M immunosorbent ag glutination assay (ISAGA) for detecting toxoplasma specific IgM. f Clin Pathol 1989;42:1291-5.

17 Chantler S, Diment J. Current status of specific IgM antibody assays. In: Voller A, Bartllett A, Bidwell D, eds Immunoassays for the 80s. Lancaster: MTP Press, 1981: 417-30.

18 Payne RA, Isaac M, Francis JM. Enzyme-linked immunosorbent assay (ELISA) using antibody class capture 1982;35:892-6. 